\title{
CHALLENGES IN DEVELOPING OF VOCATIONAL MADRASA BASED ON FOSTER FATHER
}

\author{
Erna Nurkholida \\ STAIN Kediri \\ ernanurkholida@ymail.com
}

\begin{abstract}
Abstrak
This paper described the challenges and changes in developing vocational madrasa, foster father program and the role of Nahdatul Ulama, By using descriptive qualitative research, it provided the portray of the development of vocational madrasa, the early born of Madrasah Kejuruan Maslahiyah Badas Kediri. The findings showed that students in choosing a school took interests $85 \%$, majors $80 \%$, and the last is experience $25 \%$. The variable of motivation, the most dominant factor influence is conducive learning environment was $86 \%$, desire was $85 \%$, and activities in learning was $80 \%$. The interview of the respondents stated that they were under Nahdatul Ulama organisation but it did not give so much help in developing it. They built by themself or swadaya and they stated that NU should be a bridge in buliding network with the corporations.
\end{abstract}

Key words: Vocational Madrasa, Foster Father, Nahdatul Ulama

\begin{abstract}
Makalah ini menggambarkan tantangan dan perubahan dalam mengembangkan madrasah kejuruan, program ayah angkat dan peran Nahdatul Ulama, Dengan menggunakan penelitian kualitatif deskriptif, itu memberikan gambaran perkembangan madrasah kejuruan, lahir awal dari Madrasah Kejuruan Maslahiyah Badas Kediri. Temuan menunjukkan bahwa siswa dalam memilih sekolah mengambil minat 85\%, jurusan $80 \%$, dan terakhir adalah pengalaman 25\%. Variabel motivasi, pengaruh faktor yang paling dominan adalah lingkungan belajar yang kondusif adalah 86\%, keinginan sebesar $85 \%$, dan aktivitas dalam pembelajaran adalah $80 \%$. Wawancara para responden menyatakan bahwa mereka berada di bawah organisasi Nahdatul Ulama tetapi tidak memberikan banyak bantuan dalam mengembangkannya. Mereka membangun oleh mereka sendiri atau swadaya dan mereka menyatakan bahwa NU harus menjadi jembatan di jaringan buliding dengan perusahaan.
\end{abstract}

Kata kunci: Madrasah Vokasi, Ayah Pendiri, Nahdatul Ulama

\section{Introduction}

Madrasah in the last decade of the 20th century is an alternative education institutions to educate their children. Todays madrasa students show improvent of participants as well as is increasing in perfomances from year to year. Madrasa is motivated by the circumstances and that conditioned as private organizations. Changes began to occur in the early 20th century marked the emergence of Islamic educational institutions in the form of modern public schools and madrasahs distinctively Islamic. In general, the emergence of modern institutions is characterized by changes in aspects; curriculum (introduced general subjects), methods (introducing modern teaching methods), and means (started using tables, chairs, blackboards, and the class system ).

In the early of 20th century the Dutch East Indies government to expand existing schools with low cost and a modern management system in terms of 
curriculum, methodology and infrastructure which means challenges and tough competition, especially the madrasa that are traditionally held by the figures of Islam. From this arose the idea to promote Islamic education by establishing educational institutions both individuals and institutions. Madrasa include Madrasa Adabiyah (Adabiyah School) Length of the field, West Sumatra. At this school besides religious instruction was also given the knowledge to read and write Latin letters and mathematics. In 1915 this school received recognition from the Dutch East Indies government and the changing Become HIS (Holland Inlandsche School was at the primary level. This was the first HIS in Islamic organization and the first in the Minangkabau which put religion in the lesson plan ${ }^{1}$. Another madrasa gave another lesson besides religious lessons, among others; Madrasa Diniyah in Padang Panjang in West Sumatra this school gave lessons in history and geography², while the Madrasa Putri Diniyah established in 1923 specializing in female students. In the post-independence government began to increase coaching madrasa through increased institutional status conducted by the People's School of Islam (SRI) to as much as 235 State Islamic Elementary School in 1962.

Here is the data from year to year madrasah nationalization;

\begin{tabular}{|l|l|l|l|l|}
\hline \multicolumn{1}{|c|}{ Year } & \multicolumn{1}{|c|}{$\begin{array}{c}\text { Name of } \\
\text { madrasah/school }\end{array}$} & Nationalization & Number & Specification \\
\hline & $\begin{array}{l}\text { Sekolah Rakyat } \\
\text { Islam }\end{array}$ & MIN & 235 & $\begin{array}{l}\text { SK menteri agama } \\
\text { No. 104/1962 }\end{array}$ \\
\hline \multirow{2}{*}{$1967-1970$} & MTs & MTs AIN/MAAIN & MIN 358 & SK no. 80/1967 \\
& Swasta/Aliyah & & MTs AIN 182 & \\
& Swasta & & & MAAIN 42 \\
\hline 1978 & MTs AIN/MAAIN & MTsN/MAN & Min. 1435 & SK No. 42/1992 \\
& & & MTsN 1141 & \\
\hline $1992-1999$ & PGAN & MAN & MAN 553 & \\
& & &
\end{tabular}

Besides the coaching the status of government institutions also conduct training madrasa as verified through the determination of a madrasa into the Madrasa model, namely MIN Model was 44, Model 69 was MTsN, MAN Model was 35. Madrasah was intended as a pilot, and a reference for the development of other madrasas. MAPK opening of the Madrasah Aliyah Special Program to meet the religious experts and then developed into Religious Madrasah Aliyah. In addition it also opened Vocational Madrasah Aliyah (MAK). The Madrasah which intended to give students the ability to provision in the field of specific

1 Abudin Nata, Sejarah Sosial Intelektual Islam dan Institusi Pendidikannya (Jakarta: Rajawali Press, 2012), p. 211

2 Ibid p. 210

3 Tarmi, Drs. Kebangkitan dan Perkembangan Madrasah di Indonesia (Jakarta: Gramedia, 2001), p. 207 
skills to be able to work in the community. Until now numbering of MAK was $84^{4}$.

In 2008/2009 the number of agencies being recorded as many as 19,762 of RA, MI was 21,529, 13,292 of MTs, and MA was 5,648 in the 33 provinces in Indonesia ${ }^{5}$. This year the number of state institutions has increased due to the existence of a number of private institutions are nationalized. MIN number was $1,662, \mathrm{MTsN}$ was 1,384 , and as many as MAN was 735 . The amount was not entirely because it was still waiting for nationalization decree of Ministry of Religious Affair as a new institutions.

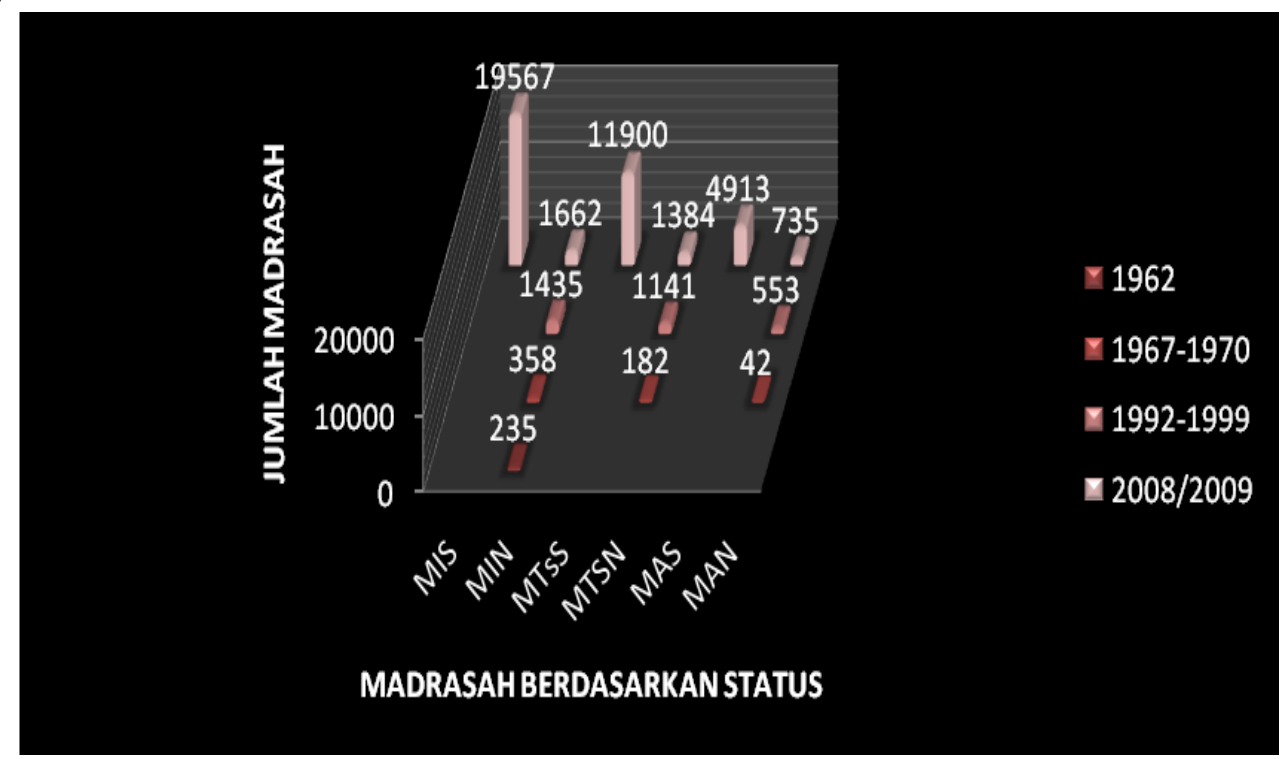

From these data it can be concluded that the madrasa is constantly increasing quantity from year to year. The existence of Madrasa since Indonesia's independence until now is essentially a continuation of madrasa since its inception in the early 20th century until Indonesia's independence. Attention and guidance that the government is very high both in terms of quality and quantity.

In the 2010-2011 academic year there were as many as 24,318 nationally Raudhatul (RA), 22,468 Elementary School, 14,757 junior secondary school, Madrasah Aliyah 6,415. Percentage distribution of institutions that successfully recorded was $36 \%$ - RA, 33\% - MI, 22\% - MTs, 9\% - MA. Here the data of 
Madrasa in 2010-20116.

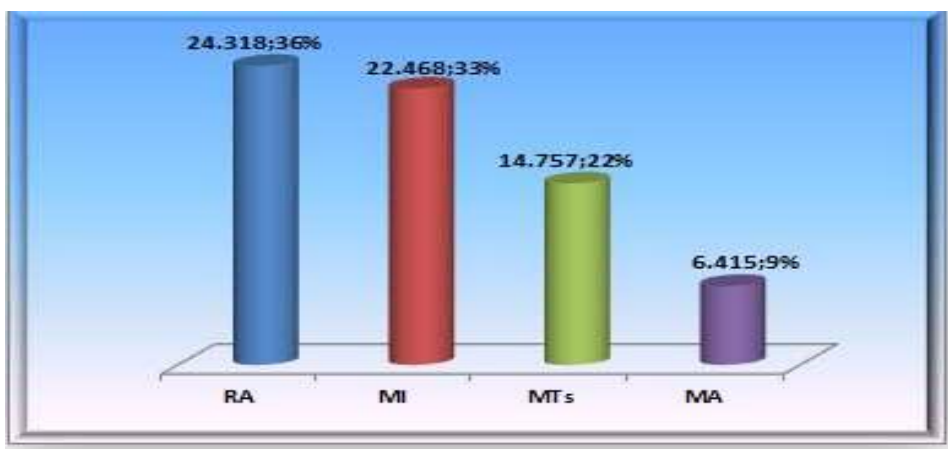

Jumlah Lembaga RA, MI, MTs, dan MA TP. 2010-2011

The number of State Islamic Elementary School District (MIN) in the academic year 2010-2011 as many as 1.686 or $7.5 \%$, while the Private Elementary School (MIS) as many as 20782 or $92.5 \%$. The number of State junior secondary school (MTsN) of 1.437 or $9.7 \%$, while the Private junior secondary school Tsanawiyah (MTsS) as many as 13.320 or $90.3 \%$. Number of Madrasah Aliyah Negeri (MAN) as many as 758 or $11.8 \%$, while the number of private Madrasah Aliyah (MAS) as many as 5.657 or $88.2 \%$. MIN number as many as 1.675 in the previous year, so that in the year 2011 there was increase by 11 institutions, while for the junior level, the number MTsN as many as 1.418 in the previous year, there were 19 institutions increase, the level of MA, MAN number 748 in the previous year, there increase by 10 institutions.

Increasing number of madrasa in 2011 was due to the nationalization, some madrasa that had been nationalized by the Ministry of Religious Affairs. In terms of the composition of the madrasa between public and private, more than $90 \%$ held by private madrasa, which developed by the foundation.

This is due partly to the amount of attention and responsibility of the community since the first of the importance of faith-based education, especially education, but it also shows the condition of education should not continue to be the responsibility of the government, but it should also be the responsibility of the community.

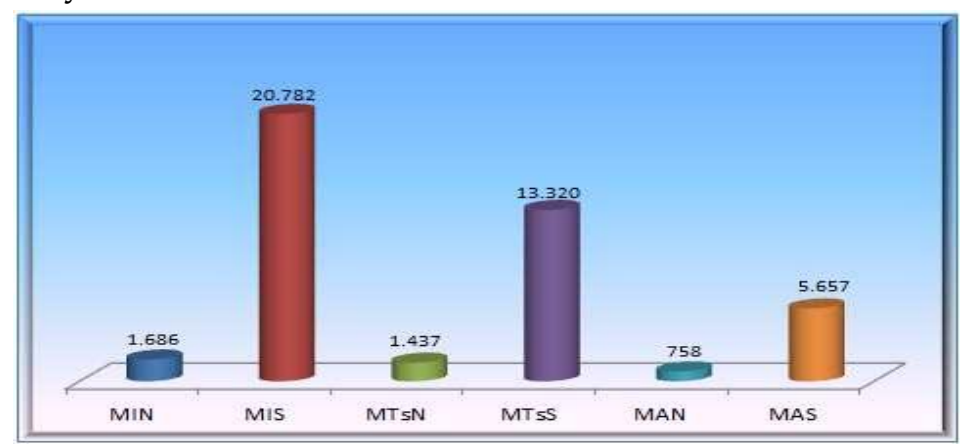

Jumlah MI, MTs, dan MA Berdasarkan Status

TP. 2010-2011

${ }^{6}$ Ibid 2010/2011 


\section{Methodology}

This research design applied in this study is descriptive design since it tries to describe the current status of the objects dealing with the variable of the study. Kartadinata describes that descriptive study emphasizes on the actual or recent problem occuring at the present time, in a local area. Although it is about the actual or recent problem, the researcher may propose certain predictions 7 . Best explain that the process of descriptive study involve the description, recording, analysis and interpretation of condition that exists 8 . More spesific, this research applies the documentary analysis. This type of analysis is conducted by examining the students' work on their answer of questionaires. All answers are then explored and analyzed comprehensively to find the type of the learning styles and learning strategies.

1. Population and Sample

The population of this study is the students of Madrasah Aliyah Kejuruan Mashlahiyah Krecek Badas Kediri and the members of foundation They are 37 respondents. There were 30 students and 7 board members.

2. Research Instrument.

The data are collected by given a qustionaire to students and board members. The questionaire consists of motivation, and interest. There are 27 questions. The qustionaire is in the form of the five point Likert scale, which is adapted from the original seven point Likert scale format of Gardner's attitude and motivation test ranging from strongly agree to strongly disagree. The other instrument is interview that consist of 4 questions.

\section{Nahdlatul Ulama}

\section{Actualizing Potential Education}

Nahdlatul Ulama (NU), is the largest Islamic organization in Indonesia. This organization was established on January 31, 1926 and engaged in education, social, and economic. The establishment of NU is essentially an institutionalization of the Islamic tradition that has lived for hundreds of years and developed in the archipelago.

NU has 13 institutions to imply NU's policy related to a certain field. One of them is Ma'arif Institute Education of Nahdlatul Ulama or LP Ma'arif NU) is an organisation under active potential organisation. It apparatus that serves as the executor of Nahdlatul Ulama's education policies, which are at the level of the Executive Board, the Regional Board, Branch Officers, and the House of Representatives Branch. LP Ma'arif NU in its journey actively involved in education development process in Indonesia. Institutionally, LP Ma'arif NU also established educational units in the form of schools and madrasah, from

\footnotetext{
7 Sunarya Kartadinata, Metode Riset Sosial, (Bandung, Prima Bandung, 1998), 16.

8 W. John Best. Research in Education. (Singapore, Prentice Hall of South-East Pte Limited.
} 1987), 25 . 
elementary, secondary, to university level. Until now, there are not less than 6000 educational institutions spread all over the country under the shelter, ranging from TK / RA, SD / MI, SMP / MTs, SMA / SMK / MA, to several universities.

With the large amount of schools, NU still needs an educational development design that can address the reality and challenges of life in its multi-faceted aspects. The future of NU can be seen from the quality of education today. The weakness of the education sector can lead to NU existential erosionnot only culturally but politically. This can only be overcome by reactivating the process of interpretation, transformation and culture of NU's values through education (formal, informal and non-formal).

In this regard, the expansion of networks with fellow educational institutions - within the NU itself and other education providers - as well as with governments, private parties and international educational institutions is a basic requirement. This is a step to respond to the people's need for quality human resources in the global era.

\section{Case Study of Vocational Madrasa at Yayasan Pendidikan dan Sosial Mashlahiyah Krecek Badas Kediri \\ Boarding School Period}

In this section we will give an overview of the struggle of foundation in striving to build vocational madrasa Mashlahiyah although "not successful", expressed here in do not work because in the end is not a vocational madrasa but the founding of vocational high school can be built. Though the founders wanted the Vocational Madrasa. Original idea came from the community and are willing to provide assistance but had to give up on the rules. Understanding the existence of Islamic history rooted in the community, both individuals and institutions would that authors provide an overview Yayasan Pendidikan dan Sosial Mashlahiyah.

Around the year 1940 at the instigation of Krecek villagers who want to learn the science of religion to Mr. H. Abdul Somad. Then began to put the boarding school founded in his home. In 1951 on the initiative of Kyai Subki stood Madrasah Diniyah Mashlahiyah first ${ }^{9}$. The curriculum is taught purely religious sciences like Jurumiyah etc.. As the development time of 1965 there Madrasa Diniyah Mashlahiyah renamed Compulsory Madrasa Education Mashlahiyah (Madrasah Wajib Belajar) with the headmaster was Mr. H. Masduqi Yasir. At that time, in addition to knowledge of religion was also given general science.

In 1970s Compulsory Madrasah Education renamed Voorclass but this did not last long and then changed the old into junior secondary school Mashlahiyah

9 With the board of management; Mr. Ky. Subki, Mr. H. Joseph. Mr Sidiq, Mr. H. Sahid, Mr. Paimin, Mr. Syarkawi, Mr. Serin, and Mr. Pangat. 
(MTs Mashlahiyah) that some alumni have become members of Parliament and civil servants in the various fields. To reinforce the existence of educational institutions H. Masduqi Yasir and H. Khotib Hidayat established Yayasan Pendidikan dan Sosial Mashlahiyah in 1976 and the chairman was H. Masduqi Yasir, and the secretary was H. Khotib Hidayat. The purpose of the Yayasan Pendidikan dan Sosial Mashlahiyah are:

1. Develop general science and religion, to join educate Indonesian people.

2. Help welfare, education in Madrasah and dormitories and boarding school.

3. Promoting cooperation umaro and scholars'.

In 1972 initiated Madrasa Aliyah Mashlahiyah but not developed and does not continue and then re-established in 1984 by Mr. H. Khotib Hidayat and KH. Afandi Fadlil Somad Mashlahiyah Madrasa board as chairman and appointed Mr. H. Khotib Hidayat as head of MAM by considering the merits of H. Nawawi in building Madrasah Maslahiyah.

\section{Vocational Madrasah Mashlahiyah}

To speed up the realization of the goals and ideals are there then in $2004 \mathrm{H}$. Khotib Hidayat nationalize Madrasah Aliyah Mashlahiyah be Madrasah Aliyah Negeri Krecek which is the only state Junior Madrasa in sub Badas. In the spirit of devotion to the education of the nation and the surrounding communities a boost in $2011 \mathrm{H}$. Hidayat Khotib with some community leaders established the Vocational Madrasah Aliyah (MAK) at the Ministry of Religious Affairs. But his efforts to establish vocational Madrasah get some constraints such as the absence of permission and guidance about vocational madrasa from ministry Religious Affairs so that make difficult for stakeholder to carry out the teaching and learning activities, frequent schedule changes and competent teacher in the vocational field is also very less so that the recruitment of teachers are potluck. Selection and recruitment of students without simply getting students provide constraints on the students who are often absent and tend to be unruly. As for the problems that exist among others ${ }^{10}$ :

\section{Foster Father}

Foster Father system can be applied to the developed madrasa to more qualified again. The application of the foster father system can use the far class system. Polytechnic or vocational school who have advanced in the class can open madrasa that are ready to be adopted school. Selection of students, teachers and facilities and all subject are to be lent from its core school. So Input and output is as far as grade students at the output of its core school. After several years of coaching, the class can break away from the core or the school of his foster father and become an independent school.

10 based on the author's experience during a teacher at the MAK 
Foster father system has happened in the world of business, this kind of mutualism system can also be applied in the educational environment by taking the principles of mutual benefit and mutual need. Foster father system is the embodiment of the business linkage program which is a form of cooperation between the Islamic/vocational school/ experienced polytechnic and as an foster father to a new madrasa. Foster father is very important, because this relationship is a bridge for small vocational madrasa to take advantage of facilities like experts, computer labs, vocational management of madrasa will be able to generate a small vocational madrasa so that later become independent madrasa and competent in its field.

Models in vocational madrasa with school foster will bring several advantages, among others:

1. Preservation of the quality of the new vocational madrasah will be better. As it is known that the new madrasa tend to go with the old concepts and perfunctory. It is only in the decline in the quality of madrasa which started up achievement.

2. Madrasa is from and for the community. Foster father gait allow people in developing madrasa so that existing problems can be solved by the people themselves, assisted by the foster father.

3. Foster father systems to be a measurement of success or failure of the program that was the brainchild of the community. Because in this system public will control and regulate everything.

4. Reduce the risk of failure. Compared to programs originating from the center of a project which, if out of contract then the activity is completed anyway without anyone continue or resume.

\section{Data Analysis}

This research employs a simple quantitative statistical method to calculate the frequency and the percentage of questionaires about interest, and motivation of Madrasah Aliyah Kejuruan Mashlahiyah Krecek Badas Kediri. The score is got by answering the questionaires with the likert scale 1-5, add the numbers together and multiply the answer by the amount of questions.

\section{Finding And Discussions}

This section presents the results of the study and discusses the findings. The first part deals with the findings about the overall interest of the students, motivation and quality. To clarify what it has already been presented, the mean scores of each aspects were calculated. Here the category of the score.

\begin{tabular}{|c|c|c|}
\hline Score Range & Average Score & Category \\
\hline$X>96.59$ & $X>4.2$ & Very good \\
\hline $78.20<X \leq 96.59$ & $3.4<X \leq 4.2$ & Good \\
\hline
\end{tabular}




\begin{tabular}{|c|c|c|}
\hline $59.80<\mathrm{X} \leq 78.20$ & $2.6<\mathrm{X} \leq 3.4$ & Enough \\
\hline $41.40<\mathrm{X} \leq 59.80$ & $1.8<\mathrm{X} \leq 2.6$ & Less \\
\hline $\mathrm{X} \leq 41.40$ & $\mathrm{X} \leq 1.8$ & Very less \\
\hline
\end{tabular}

As the total number of the participants were 37. The students were 30 and the Mashlahiyah board members were 7 persons. From 2 categories of respondents, the researcher questioner was given to the students and interview was given to the Mashlahiyah board members.

Table 2 showed the percentage of questionaire from the students that consist of interest.

Table 2 Percentage of Interest

\begin{tabular}{|l|l|c|}
\hline \multicolumn{1}{|c|}{ No. } & \multicolumn{1}{|c|}{ Factors } & Percentage \\
\hline 1. & Major & 80 \\
\hline 2. & Interest & 85 \\
\hline 3. & Facilities & 70 \\
\hline 4. & Experience & 25 \\
\hline 5. & Environment & 70 \\
\hline 6. & Participation & 75 \\
\hline
\end{tabular}

The most dominant in influencing student in choosing a school are interests $85 \%$, majors $80 \%$, and the last is experience $25 \%$. It showed that students had high desire to join vocational madrasah. Then they choosed major as their preference as it will prepare them in the future. The last choice is experience, students thought it was not matter when the school did not have experience in operating the vocational madrasa. Next to the motivation, can be seen in table 3 below:

Table 3 The Percentage of Motivation

\begin{tabular}{|c|c|c|}
\hline No. & Factors & Percentage \% \\
\hline 1. & Desire & 85 \\
\hline 2. & Hope & 65 \\
\hline 3. & A Conducive Learning \\
& Environment & 86 \\
\hline 4. & Activities in Learning & 75 \\
\hline 5. & Awards in Learning Interesting \\
\hline
\end{tabular}

In the variable of motivation, the most dominant factor influence is conducive learning environment was $86 \%$, desire was $85 \%$, and activities in learning was $80 \%$. In the world of education, motivation is needed in helping the learning process as well meet the needs of the students. The condusive learning 
environment is extrinsic motivation. With the extrinsic motivation, students are expected to be able to achieve maximum learning outcomes. While desire is an intrinsic motivation that is a motivation from within students to learn. When motivation extrinsic and intrinsic can go hand in hand so it will produce learning outcomes the good one.

\section{Interview Result}

There were 4 questions to the board members. The first questions was about the people's role in developing vocational madrasa. They absolutly agree with this innovation. It was based on the history of the madrasa aliyah and tsanawiyah that has been existed before. It was built from the contribution of the residents.

The second question was about what the contribution of Nahdlatul Ulama in developing vocational madrasa. There were 1 person stated that it gave good contribution, while 4 persons stated there was not contribution and 2 person stated that NU gave litle contribution. They explained that contribution mean the motherboard of the foundation was Nahdlatul Ulama. While the persons who stated there was not contribution meant that during this time NU did not give help in developing vocational madrasa namely network or financial.

Next question was about the barriers of developing vocational madrasa. Surprisingly, they stated that the member of foundation did not have network to help it. Mr. Khotib stated that it was difficult to find sponsorship in assisting it. While Mr. Supadi added that big organisation namely NU could to be bridge in searching sponsorship. But it was not happen. Besides that they also gave some problems namely:

Licensing Issues; Since the birth of the regulations No. MA/111/2011 and 14/VI/PB/2011 government regarding acceptance of students in kindergarten / RA / BA sekolah / madrasah. In Article 22 vocational Madrasah Aliyah (MAK) is one form of formal education unit in the Ministry of Religious Affairs who assisted vocational education to the specific religion in secondary education as a continuation of the SMP, MTs, or its equivalent or other form of advanced learning outcomes recognized the same / equivalent SMP / MTs. This regulation has been mentioned but in fact Vocational Madrasa license from the Ministry of Religious Affairs can not be given because of the technical vocational madrasa guidelines yet exist. After waiting two and a half years finally obtained permission on the national education ministry. While the permission of the Ministry of Religious Affairs can not be given.

Majors Problems; In the absence of permission to make teaching and learning activities are not going well frequent disassembly due to the alternation of major subjects being taken. At the beginning of deliberation approved the establishment of MAK is majoring in engineering machinery but in fact the lack of teachers who competence in its field. This gives rise to confusion on the 
learner. Disassembly subjects often occurred during the two years since adjusting where appropriate teachers in their field. But in reality the absence of incoming student selection and the average student is enrolled drop out. This of course makes the students become unruly and undisciplined. Besides the competence of children is also very low.

Learners Problems; MAK learners as the PP mentioned above is the requirement of article 13 prospective new students grade 10 (ten) SMK / MAK; has passed SMP / MTs / SMPLB / Program Package B and has a diploma; has SKHUN; highest aged 21 (two twenty-one) years old at the start of the new school year, and qualified in accordance with the specific field of study skills / study skills / competency skills in SMK / MAK intended. But in reality the absence of incoming student selection and the average student is enrolled drop out. This of course makes the students become unruly and undisciplined. Besides the competence of children is also very low. Today students grade $x$ are 23 and class XI are 17 students.

Human Resource Problem; Human Resources became the principal power in the madrasa, in society there is a sincerity that can not be replaced with any material. Mutual cooperation to achieve the goal of establishing madrasa very high among Krecek rural communities.

Decades, they from generation to generation helped develop many madrasa that brings benefits to them. But the sincerity of their hearts was not accompanied by insight, and skills to respond to the challenges of time. The means taken in developing vocational madrasa still like the old days when applied at this time will only bring setbacks madrasa.

As in the crawl pupil, in the absence of selection and tests related to the ability of all students accepted. Similarly, in the management of madrasa management, they decided not to pick up her school fees the initial entry and ultimately learning activities to be unable to walk properly due to lack of funds. Even if there is income of financial institutions or individual grants held by one person that causing diversion.

In Human resource issues at the MAK of Mashlahiyah figures still dominate centralized leadership. So many decisions to be based on the figure. Quite often appear dictatorship in expressing ideas, as in the opinion of some majors are computer science, but because the figure wanted engineering machinery audience was forced to agree it.

Due to the dictatorship of the leaders often decide things on their own without any consultation with the teachers or the board of a foundation that raises another issue. Now MAK Mashlahiyah has 11 teachers, three of them doubles as an administrative staff.

Financial Problem; As for asset MAK is having a building with two floors consisting of six classes. All of which is owned by the Foundation of Education and Social Mashlahiyah, while overall students studying at MAK not charge a fee 
or free even given a uniform was attempted. This is done to be able to recruit as many students. But it is also an obstacle in the learning process, these activities become sober and tends towards the deterioration of education. Help comes to incidental and used to cover the needs of each school day such as stationery and office equipment.

The last questions was the efforts done by the commite in developing vocational madrasa. They said that they run the school as well as possible while waiting from the donatur. They also added that the bold line in developing vocational madrasa was network with the corporation, like computer corporation, motor and etc.

\section{Conclusion}

Vocational madrasa is the model of contextual learning. In this case the teacher can encourage learners to be able to connect knowledge with real life and be able to solve the issue in everyday life. Training to achieve this capability can be done on the job (practicing to work) and off the job (practicing outside of work). Here reserved space to convey theory and practice. Vocational madrasa can be a vehicle for religious values and culture, which combines theory and practice of teaching to the proportion of $30 \%$ versus $70 \%$. By considering the expected competencies, appropriate expertise.

Nearly 90 percent of madrasa run by private organizations so that more public role. For the development of vocational madrasa need attention and support from various parties such as: government and private corporation. In this case the government should look at the twisted idea of community by providing facilities such as guidance on the licensing terms of the physical form of management and provide ongoing assistance. The business community can also provide assistance in the form of facilities for the training and information necessary business skills current.

School attendance by foster father system is judged to have a high standard and quality. Madrasa and pesantren with the system could be an alternative for vocational education in Indonesia. Foster father is one of the strategic instrument for the development of new vocational madrasa. By understanding the various aspects of partnership and cooperation to join in the container, the new vocational madrasa together will have top notch quality and strong enough to face the challenges of the times so as to equal, interdependent, and mutually reinforcing.

The involvement of such main organizations like NU is so minimal that it is less able to support existing innovations. It is hoped that the organization has more role in giving network to companies so that madrasa is more easily developed.

In the future, it needs to hand by hand make networking between NU and corporation to assist the vocational madrasa. 


\section{References}

-2009. Sekolah Life Skill, Lulus Siap Pakai!. Yogjakarta, Diva Press

-2011. Tips Efektif Pemanfaatan Technologi Informasi dan Komunikasi dalam Dunia Pendidikan. Yogjakarta: Diva Press

Ahid, Nur, Problematika Madrasah Aliyah di Indonesia, Kediri, Stain Press, 2009.

Al Quran dan Terjemahannya

Aly, Hery Noer, Pendidikan Islam Kini \& Mendatang, Jakarta: Triasco, 2000

Asmani, Jamal Ma'mur. 2013. Kiat Melahirkan Madrasah Unggulan Merintis dan Mengelola Madrasah yang Kompetitif, Yogjakarta: Diva Press

Bakar, Marzuki Abu. 2012. Pesantren Kejuruan Sebagai Salah satu Alternatif Pengembangan Lembaga Pendidikan, Makalah AICIS 2012.

Fatchurahman, Nanang. 2012. Madrasah Sekolah Islam Terpadu, Plus, dan Unggulan, Cet. Ke-2. Depok: Lentera Hati Pustaka

http://pendis.kemenag.go.id

Kholiq, Abdul. 2011. Pendidikan Ketrampilan pada Madrasah Aliyah. Semarang: Walisongo Press

Mahfudh, M.A. Sahal. 1999. Pesantren Mencari Makna. Jakarta: Pustaka Ciganjur dan Keluarga Mathali'ul Falah (KMF) Jakarta.

Maksum, Madrasah Sejarah dan Perkembangannya, Jakarta: Logos, 1999

Muhaimin, Pengembangan Kurikulum Pendidikan Agama Islam di Sekolah, Madrasah dan Perguruan Tinggi, Jakarta : PT Raja Grafindo, 2005.

Mulyasa, E. 2007. Menjadi Kepala Sekolah Profesional, Cet. Ke-9. Bandung: Rosda Karya.

Munawir, A.W., Kamus Al-Munawir Arab-Indonesia, Yogyakarta: Pustaka Progressif, 1997

Nata, Abuddin, Sejarah Pertumbuhan dan Perkembangan Lembaga-Lembaga Pendidikan Islam di Indonesia, Jakarta, Gramedia, 2001

Nawawi, Imam, Riyadus Shalihin versi digital.

NurKholida, Erna. 2012. Islamic International School; Wilted before Growing; Critical Study on Madrasa Curriculum. Makalah AICIS 2012.

Peraturan Menteri Agama Republik Indonesia nomor 2 tahun 2008 tanggal 6 Mei 2008 tentang Standar Kompetensi Lulusan dan Standar Isi Pendidikan Agama dan Bahasa Arab di Madrasah.

Rahmat, Raharjo, Inovasi Kurikulum Pendidikan Agama Islam, Yogyakarta: Magnum, 2010.

Subhan, Arief. 2012. Lembaga Pendidikan Islam Indonesia Abad ke 20, Pergumulan Antara Modernisasi dan Identitas. Jakarta: Kencana Prenada Media.

Suyud, Tatang M. Amirin dan Nurlina Marliyasari Asih, Model Anak Angkat dalam peningkatan Kualitas Sekolah ( Kasus Sekolah Dasar Muhammadiyah Condongcatur, Yogjakarta) Jurnal International Manajemen Pendidikan online. 